\title{
DEVELOPING ISLAMIC FINANCIAL TECHNOLOGY IN INDONESIA
}

\author{
Aam Slamet Rusydiana \\ Sharia Economic Applied Research \& Training (SMART) Indonesia
}

\begin{abstract}
Financial technology in Indonesia is an untapped market opportunity. As the world's largest population Muslim country, the prospects for Islamic fintech in Indonesia seem very bright. This study tries to answer what problems, foundations and key ecosystem or stakeholders are involved in the development of Islamic fintech in Indonesia using Interpretive Structural Model (ISM) approach.

The core problems faced in the development of Islamic financial technology industry are: Lack of policy instruments guarding the fintech work process, and availability of human resources for fintech. The core strategies or foundations that's needed in framework of Islamic fintech development are: Ability to manage and analyze data in big data era, and Human resources in digital marketing. For the aspects of Ecosystem or Actors involved in the development of Islamic fintech in Indonesia, the important actor is: Government or regulator, Educational institutions (universities), and also Existing industries (banks and other financial institutions).
\end{abstract}

Keywords: Islamic Fintech, Interpretive Structural Model, Islamic Finance, ISM JEL Classification: G23, O14, O33. 


\section{INTRODUCTION}

Financial technology or Fintech in Indonesia is an untapped market opportunity. The vast geography of the lands, considerable middle-class growth and poor penetration of financial products altogether combine to create a formidable market for the development of fintech in Indonesia. With only 36\% of the population having a bank account, fintech in Indonesia holds the promise of delivering accessible financial services to the unbankable population in the country. It is noteworthy to highlight that platforms of fintech in Indonesia grow by leaps and bounds from year 2015 to end of 2017 (Hasan, 2018).

As the world's largest population Muslim country, the prospects for Islamic fintech in Indonesia seem very bright. Overall, fintech in Indonesia has huge and great potential as it can provide solutions for pressing needs which traditional financial institutions are not able to provide. Moreover, an explosion in mobile penetration (70 percent use mobile phones to access the web) in the country has created a fertile ground for fintech's rapid rise.

In the current development, the financial technology industry or known as 'financial technology' or Fintech industry has various types. There are at least four types of fintech industry in Indonesia: The relatively large fintech industry, start up fintech, social fintech and fintech with 'loan market' type.

For Startup Fintech type, some of them are: Doku, iPaymu, midtrans, kartuku, and dimo. Meanwhile the Fintech type that has been longer and quite large, among others: Amartha, crowdo, investree, and koinWorks. The type of Social Fintech we can find it such as: kitaBisa, gandengTangan and wujudkan. The financial technology industry of the type of Loan Market are: bareksa, infovesta, stockbit, indoPremier,
indoGold, and olahdana.

Financial Services Authority (OJK) as the referee of the financial industry has issued a legal standing for fintech industry. The legal umbrella is in the form of OJK Regulation No. 77/ POJK.01/2016 concerning the Peer-to-Peer Lending / $\mathrm{P} 2 \mathrm{P}$ Lending Service Borrowing Service issued at the end of December 2016. However, the rules are only set up fintech with conventional systems, and has not regulated the sharia system that is now also beginning to grow.

This research tries to answer some of the following research questions: First, what problems faced in the development of Islamic fintech in Indonesia. What strategies or foundations are necessary and crucial in the framework of developing Islamic fintech. Furthermore, any key ecosystem or stakeholders are involved in the development of Islamic fintech in Indonesia. Through research using Interpretive Structural Model (ISM) approach, some of the above questions will try to be answered.

\section{LITERATURE REVIEW}

KPMG defines fintech simply as technology-based businesses that compete against, enable and/or collaborate with financial institutions (Pollari, 2016). In the other definition, Chuen and Teo (2015) state that fintech refers to innovative financial services or products delivered via new technology. From this way, Islamic fintech means technology-based businesses with innovative financial services or products using Islamic or shariah scheme. Islamic Fintech promotes ethical responsible finance, and presents an opportunity to lead and influence all forms of finance globally.

Fintech firms can be classified as: a) Information technology and software firms supporting and facilitating the financial sector firms more so termed as 
bank technology service providers, and b) Tech-startups and small innovative firms substituting the regular financial intermediary, the ease of accessibility to which can cause 'disruptions' for mainstream banks and banking systems.

Harrison et al (2014) show that business innovations stimulate economic development on both micro and macro levels. The application of information technology in the finance industry is a field with great potential for innovations; therefore, both enterprises and investors are highly interested in it.

Webster and Pizalla (2015) point out that competition between fintech and traditional banking services gets more intense every year due to continuing development of information technology. Simultaneously, fintech increases the Interest in modern financial services from progressive financial institutions that aim to maintain and strengthen their leading role in the field and provide modern services of high quality in a convenient and effective form for their clients anywhere, anytime. Recently the collaboration between traditional financial institutions and fintech branch is growing as both parties see promising avenues for further development.

Based on literature studies and indepth interviews, some researchs related to the development of Islamic financial technology with ISM framework is divided into four criteria: (1) Perspective of fintech function, (2) Problems faced in developing Islamic fintech, (3) Strategy or foundation required within the framework of developing Islamic fintech, and (4) Ecosystems or actors involved in the development of Islamic fintech in Indonesia.

In the criteria of functions and roles of financial technology, today, several functions commonly used through Islamic fintech, including: (a) Online financial transactions, (b) Electronic money or emoney, (c) Virtual accounts, (d) Aggregator, (e) Lending, (f) Crowdfunding, and (g) Personal finance planning (Saksonova and Merlino, 2017).

Meanwhile, from the aspects of the problems and challenges faced in the development of Islamic financial technology industry, the following are some of the problems: (a) Lack of policy instruments guarding the fintech work process from upstream to downstream (Pollari, 2016), (b) availability of human resources for fintech, (c) High security risks from malware attacks (Saksonova and Merlino, 2017), (d) Legal certainty of online-based loans, (e) Not reaching lower-class consumers, (f) Lack understanding of sharia, and (g) the need for improvement in aspects of governance, accounting and sharia auditing.

From the aspect of strategy or foundation that's needed in framework of Islamic fintech development, especially in Indonesia, here are some of them: (a) Ability to manage and analyze data in big data era, (b) Technological infrastructure improvement, (c) Creating transaction system easily, (d) Contentbased marketing in terms of digital marketing, (f) Establishing cooperation, collaboration and investment with relevant stakeholders; (g) Fintech product innovation (Saksonova and Merlino, 2017).

Asfortheaspects ofEcosystemor Actors involved and related in the development of Islamic fintech in Indonesia are: (a) Government or regulator, (b) Shariah Fintech Industry, (c) Existing industries (in this case banks and other financial institutions), (d) ) Venture capital, (e) Educational institutions (universities), (f) Providers of network infrastructure/ internet, and (g) DPS-DSN MUI.

\section{METHODOLOGY}

Interpretive structural modeling is an advanced planning methodology 
used to identify, analyse and summarize various relationship among factors that define a problem, model or issue (Sage, 1977). ISM provides a means by which researchers or academician can impose an order and create models around factors of a system by developing the complexity of relationships among them (Warfield, 1974).

The method is 'interpretive' in the sense that the expert decisions develop the relationships among the variables. It is 'structural' on the basis of proposed relationships that create an overall structure extracted from a complex set of factors. Its a 'modeling' technique as the specific relationship and overall structure are portrayed carefully in a graphical model as well as words (Li and Yang, 2014). As a modeling technique, ISM has been extensively used in different domains to understand the relationship among the various factors that contribute to a whole system (Faisal and Al-Esmael, 2014). ISM analysis and modeling can help managers and practitioners visualize issues through a systems approach. It can then identify factors that have high levels of influance and therefore require significant attention and effort to resolve them (Jabeen and Faisal, 2018).

Interpretative Structural Modeling is a decision making method took from the complexity situation by correlating and organizing the idea into the visual map. ISM basic concept is using expert and practitioners to generate complexity system into some sub system (element) and build a hierarchy structural modeling. ISM also used to give the basic understanding from the complexity situation, and arranging the strategy to solve the problems (Gorvett and Liu, 2007).

There are some step to analyze ISM method, first stage is problem decomposition to the expert or practitioners (who has better understanding related to the problem discussed/ brainstorming) to identify the ideas of the organization development, has better understanding about financial technology development problem. From this discussion, will be explored the development strategies, and the variables used in ISM model. Second stage is constructing Structural Self Interaction Matrix (SSIM) model. SSIM is constructed from the variables founded from decomposition step, then develop the contextual relationship among variables and gathering into one variable $\mathrm{i}$ and variable $\mathrm{j}$.

Third stage is creating reachability matrix (RM) by conversing the $\mathrm{V}, \mathrm{A}$, $\mathrm{X}$, and $\mathrm{O}$ used into the numbers 1 and o. Forth stage is creating canonical matrix to identify the level through the iteration. If the intersection is not found anymore, next step is creating the model resulted from the ISM software. The model resulted used to solve the problem (in this study: Islamic fintech model development problem). From the model also explored the road map of organization development (level).

According to Marimin (2004) the process of ISM method is calculated according to the Transivity Rule where the correction of SSIM is done until a closed matrix occurs. SSIM modifications require input from panelists / experts, with special notes for attention shown only on certain sub-elements. The revised results of the SSIM and the matrix eligible for the Transivity Rules are further processed. For revision can also be done transformation matrix with computer program.

Table 3.1 Interconnection between Sub-elemen in ISM

\begin{tabular}{lll}
\hline No. & Type & Interpretation \\
\hline 1. & Comparative & $\begin{array}{l}\text {. A more important } \\
\text { than B }\end{array}$ \\
\hline
\end{tabular}




\begin{tabular}{|c|c|c|}
\hline 2. & Definitive & $\begin{array}{l}\text {. A is attribut of B } \\
\text {. A including inside B } \\
\text {. A interpret B }\end{array}$ \\
\hline 3. & Influence & $\begin{array}{l}\text { A cause B } \\
\text { A is the cause of B } \\
\text {. A develop B } \\
\text {. A move B } \\
\text {. A improve B }\end{array}$ \\
\hline 4. & Spiral & $\begin{array}{l}\text { A is south/north B } \\
\text {. A above B } \\
\text {. A to the left B }\end{array}$ \\
\hline 5. & Temporate/Time Scale & $\begin{array}{l}\text { A precedes B } \\
\text {. A follow B } \\
\text {. A have more priority } \\
\text { then B }\end{array}$ \\
\hline
\end{tabular}

There are several studies on Islamic economics and finance that have been done using the ISM method. Some of them are done by Rusydiana and Devi (2018) about sharia cooperatives, Ascarya et.al (2012) about development of shariah banks, and Devi and Rusydiana (2016) on group lending model. Meanwhile Bolanos et.al (2005), and Kanungo \& Batnagar (2002) for other industrial applications. The research using ISM method with more theoretical has been done by Lee (2007) and Takkar et.al (2007).

\section{ANALYSIS AND DISCUSSION}

To develop the contextual relationship among the factors, the ISM method suggests the use of experts opinions. For this research, an expert group was formed by contacting several academicians and practitioners. To develop the model initially, we decided to follow the traditional method of conducting a brainstorming and depth interview, where we could receive inputs of the expert and revise simultaneously. A summarized literature on Islamic financial technology development was communicated to the experts.

For analyzing the relationships among the enablers of Islamic financial technology development, a contextual relationship of 'leads to' type was chosen, meaning that one enabler led to another.
On the basis of this, the contextual relationship between the factors was developed. Experts were asked in questionnaire to compare the column statement with the row statement for each cell and to choose a value from the set $(\mathrm{V}, \mathrm{A}, \mathrm{X}$ and $\mathrm{O})$ to represent their perception of direct relationship between two sources at each time.

\section{Structural self-interaction matrix (SSIM)}

The 7 variables were put in a row and column format (in financial technology function), where variables in rows and columns are represented by $\mathrm{i}$ and $\mathrm{j}$, respectively. Thus, each pair of variables is analysed separately after the formation of grid, which was obtained in the above process. Four keywords are used to represent the direction of the relationship between a set of the variables ( $i$ and $j$ ):

(a) $\mathrm{V}$ indicates that variable $\mathrm{i}$ helps to achieve variable $\mathrm{j}$;

(b) A indicates that variable $\mathrm{j}$ helps to achieve variable $\mathrm{i}$;

(c) $\mathrm{X}$ indicates that variable $\mathrm{i}$ will help to achieve variable $\mathrm{j}$ and variable $\mathrm{j}$ will help to achieve variable $i$, or causality relationship; and

(d) $\mathrm{O}$ indicates that variable $\mathrm{i}$ and $\mathrm{j}$ are unrelated.

The relationships between variables are presented in a matrix known as structural self interaction matrix (SSIM) with the value for each pair of variable being an agreed upon value among experts.

Table 4.1. Structural Self Interaction Matrix (SSIM)

\begin{tabular}{lllllllll}
\hline No & $\begin{array}{c}\text { Variable } \\
\text { description }\end{array}$ & 7 & $\mathbf{6}$ & $\mathbf{5}$ & $\mathbf{4}$ & $\mathbf{3}$ & $\mathbf{2}$ & $\mathbf{1}$ \\
\hline $\mathrm{A} 1$ & $\begin{array}{l}\text { Online financial } \\
\text { transaction }\end{array}$ & $\mathrm{V}$ & $\mathrm{X}$ & $\mathrm{O}$ & $\mathrm{O}$ & $\mathrm{V}$ & $\mathrm{A}$ & \\
\hline $\mathrm{A} 2$ & $\begin{array}{l}\text { Electronic mon- } \\
\text { ey (eMoney) }\end{array}$ & $\mathrm{O}$ & $\mathrm{V}$ & $\mathrm{A}$ & $\mathrm{V}$ & $\mathrm{O}$ & \\
\hline $\mathrm{A} 3$ & Virtual account & $\mathrm{V}$ & $\mathrm{A}$ & $\mathrm{X}$ & $\mathrm{O}$ & & \\
\hline $\mathrm{A} 4$ & Aggregator & $\mathrm{A}$ & $\mathrm{A}$ & $\mathrm{X}$ & & & \\
\hline $\mathrm{A} 5$ & Lending & $\mathrm{X}$ & $\mathrm{V}$ & & & & \\
\hline
\end{tabular}




\begin{tabular}{lll}
\hline A6 & Crowdfunding $\quad \mathrm{V}$ \\
\hline A7 & $\begin{array}{l}\text { Personal finance } \\
\text { planning }\end{array}$ \\
\hline
\end{tabular}

Notes: Entry in the cell: V when row influences the column; A when column influences the row; $\mathrm{X}$ when row \& column influences each other; and $\mathrm{O}$ when there is no relation between row \& column.

\section{Reachibility matrix}

The reachibility matrix is obtained from structural self interaction matrix (SSIM) using a two-step process. In the first step, the alphabets used to indicate the relationships among the variables in SSIM are replaced by "O" or " 1 ". The value in the reachibility matrix depends on the type of relationship in the SSIM (Faisal, 2015) and is summarized below:

(1) If the relationship between a variable in a row with another variable in a column is " $V$ ", then in the initial reachibility matrix, the row entry becomes " 1 " while the column entry between these two variables becomes "o";

(2) If the relationship between a variable in a row with another variable in a column is " $\mathrm{A}$ ", then in the initial reachibility matrix, the row entry becomes "o" while the column entry between these two variables becomes " 1 ";

(3) If the relationship between a variable in a row with another variable in a column is " $\mathrm{X}$ ", then in the initial reachibility matrix, the row entry becomes " 1 " while the column entry between these two variables becomes "1";

(4) If the relationship between a variable in a row with another variable in a column is " $O$ ", then in the initial reachibility matrix, the row entry becomes "o" while the column entry between these two variables becomes "o";

Based on the above rules, the initial reachibility matrix for the enablers to Islamic financial technology development is constructed. Next, by incorporating transitivities (Ravi, 2015), the final reachibility matrix is obtained. The transitivity of the contextual relation is a basic assumption made in the ISM. It states that if variable $\mathrm{X}$ is related to $\mathrm{Y}$ and $\mathrm{Y}$ is related to $\mathrm{Z}$, then $\mathrm{X}$ is necessarily related to $\mathrm{Z}$ (Venkatesh et.al, 2015; Jabeen et.al, 2017). The reachibility matrix also provides the driving power and dependence power of each enabler. Thus, in the table final reachibility matrix, the driving power for $\mathrm{A} 1$ (online financial transaction) is the sum total of the values of the entries in the row, which is 7 . The dependence (the sum of the entries in the column) is 4. Similarly, the values of driving power and dependence are calculated for all the remaining enablers.

Table 4.2. Final Reachibility Matrix (RM)

\begin{tabular}{clccccccccc}
\hline No & $\begin{array}{l}\text { Variable } \\
\text { description }\end{array}$ & $\mathbf{1}$ & $\mathbf{2}$ & $\mathbf{3}$ & $\mathbf{4}$ & $\mathbf{5}$ & $\mathbf{6}$ & $\mathbf{7}$ & $\begin{array}{c}\text { Driving } \\
\text { power }\end{array}$ \\
\hline 1 & $\begin{array}{l}\text { Online } \\
\text { financial } \\
\text { transaction }\end{array}$ & $\mathbf{1}$ & $\mathbf{1}$ & $\mathbf{1}$ & $\mathbf{1}$ & $\mathbf{1}$ & $\mathbf{1}$ & $\mathbf{1}$ & 7 \\
\hline 2 & $\begin{array}{l}\text { Electronic } \\
\text { money } \\
\text { (eMoney) }\end{array}$ & 1 & 1 & 1 & 1 & 1 & 1 & 1 & 7 \\
\hline 3 & $\begin{array}{l}\text { Virtual } \\
\text { account }\end{array}$ & 1 & 1 & 1 & 1 & 1 & 1 & 1 & 7 \\
\hline 4 & Aggregator & 0 & 0 & 0 & 1 & 0 & 1 & 0 & 2 \\
\hline 5 & Lending & 1 & 1 & 1 & 1 & 1 & 1 & 1 & 7 \\
\hline 6 & Crowdfunding & 0 & 0 & 0 & 0 & 0 & 1 & 0 & 1 \\
\hline 7 & $\begin{array}{l}\text { Personal } \\
\text { finance } \\
\text { planning }\end{array}$ & 0 & 0 & 0 & 0 & 0 & 1 & 1 & 2 \\
\hline & $\begin{array}{l}\text { Dependence } \\
\text { Power }\end{array}$ & 4 & 4 & 4 & 5 & 4 & 7 & 5 & \\
\hline
\end{tabular}

From the final reachibility matrix, the next step is to establish reachibility and antecedent sets. The reachibility set for a particular enabler consists of the enabler itself and the other enablers that it may help achieve. Similarly, the antecedent set consists of the enabler itself and the other enablers that influence it. The intersection of these sets is derived for all 
the enablers. The enablers for which the intersection and reachibility set are the same form the top level of the hierarchy in the ISM model. These enablers would not help achieve any other enabler above their level (Jabeen and Faisal, 2018). The identified levels help in building the diagraph and the final model of ISM.

\section{MICMAC Quadrant Analysis}

On his research, Godet (1986) has popularized the matrix of cross impact multiplications applied to classification (MICMAC) analysis to classify the variables of the system under study. The basis of this classification is the driving power and dependence calculated in the final reachibility matrix. Additionally, the MICMAC analysis may be used for examining direct and latent relationships among enablers obtained from the ISM technique. Thus, based on the driving power and dependence, enablers in the present study are classified into four clusters, as shown and explained below:

(1) Autonomous variables: These variables have neither high driving power nor high dependence. They are detached from the system, with which they have few links that may be very strong. Quadrant I represents autonomous variables. In this study, none of the variables fall into this category.

(2) Dependent variables: Quadrant II represents dependent variables that have low driving power and high dependence. From the MICMAC analysis, enabler 4, 6 and 7 are dependent variables. That is aggregator, crowdfunding and personal finance planning.

(3) Linkage variables: These variables have high driving power and high dependence. Their characteristic is that any action on them will have an effect on the variables above their level and a feedback effect on themselves. Quadrant III represents linkage variables. In the present research, enabler 1, 2, 3 and 5 would fall in the category of linkage variables. Online financial transaction, emoney, virtual account and lending function include in linkage variables.

(4)Independent variables: These variables have high driving power and low dependence. They represent Quadrant IV. None of the variables fall into this category.

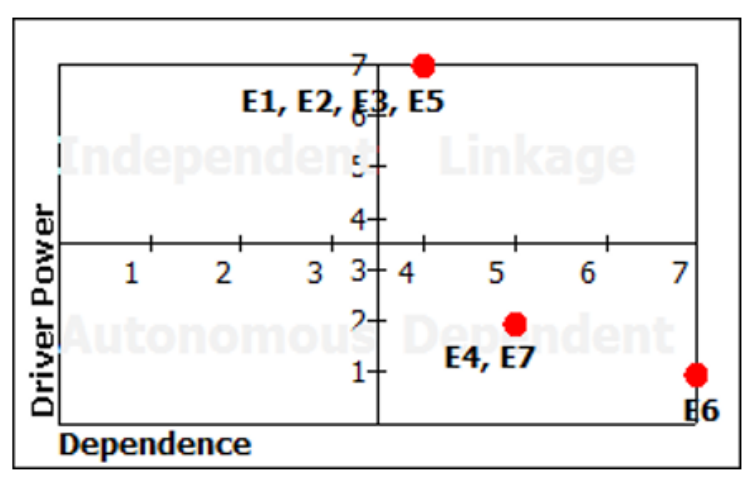

Figure. 4.1. MICMAC Analysis of Fintech Function

\section{Discussion}

From the aspects of the problems and challenges faced in the development of Islamic financial technology industry, the core and basic problems are: (a) Lack of policy instruments guarding the fintech work process, (b) availability of human resources for fintech, (c) High security risks from malware attacks, and (e) Not reaching lower-class consumers (Level 3). The next problems are: (d) Legal certainty of online-based loans, and (g) the need for improvement in aspects of governance, accounting and sharia auditing (Level 2). Last but not least is (f) Lack understanding of sharia (Level 1).

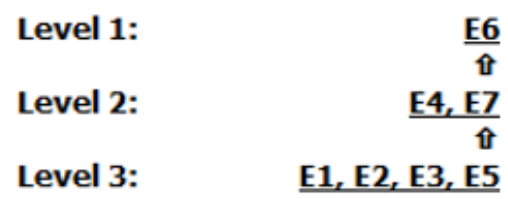

Figure. 4.2. Level of Islamic Fintech Problems

In OJK Regulation no. 77/ 
POJK.01/2016 on Direct Technology Based Loan Borrowing Services, the concept of sharia is not including. Similarly, beleid that being compiled by OJK, where the concept of sharia will not be contained in it. OJK explained that the rules to be compiled by OJK are umbrella. That means the regulation governs fintech company in general. However, it is possible that the authority will issue special regulation in the near future. Moreover, the syariah-based financial services market is quite popular.

From the aspect of strategy or foundation that's needed in framework of Islamic fintech development, especially in Indonesia, the core foundation is (a) Ability to manage and analyze data in big data era (Level 5). The next foundation is (e) Human resources in digital marketing (Level 4) follow by (c) Creating transaction system easily (Level 3). Content-based marketing and (g) Fintech product innovation are the next level of fintech foundation, and the last but not least is (b) Technological infrastructure improvement, and (f) Establishing cooperation, collaboration and investment with relevant stakeholders.

\begin{tabular}{|c|c|}
\hline Level 1: & $\underline{\mathrm{E2}, \mathrm{E6}}$ \\
\hline Level 2: & $\underline{E 4, E 7}$ \\
\hline Level 3: & $\frac{\mathrm{E} 3}{\mathrm{t}}$ \\
\hline Level 4: & $\frac{E 5}{\hat{t}}$ \\
\hline Level 5: & $\underline{E 1}$ \\
\hline
\end{tabular}

Figure. 4.3. Level of Islamic Fintech Foundations

For the aspects of Ecosystem or Actors involved and related in the development of Islamic fintech in Indonesia, the important actor is: (a) Government or regulator, then (e) Educational institutions (universities), (c) Existing industries (in this case banks and other financial institutions), (d)
Venture capital, (f) Providers of network infrastructure/internet, and (g) DPSDSN MUI. All actors then will influence the development of (b) Shariah Fintech Industry.

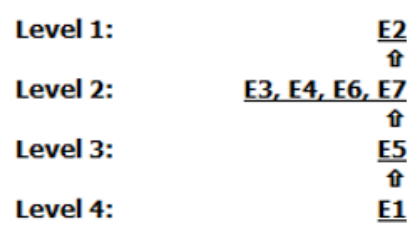

Figure. 4.4. Level of Islamic Fintech Development Actors

As we know, the government significantly influences the development of sharia finance industry in general. Likewise the fintech industry. In this case, the regulation that provides support will be expected to help facilitate the development of the shariah fintech industry in the future.

\section{CONCLUSIONS}

In general, fintech in Indonesia has huge and great potential as it can provide solutions for pressing needs which traditional financial institutions are not able to provide, especially Islamic fintech. Based on analysis, the development of Islamic financial technology with ISM framework is divided into four criteria: (1) Perspective of fintech function, (2) Problems faced in developing Islamic fintech, (3) Strategy or foundation required within the framework of developing Islamic fintech, and (4) Ecosystems or actors involved in the development of Islamic fintech in Indonesia.

The core problems and challenges faced in the development of Islamic financial technology industry are: Lack of policy instruments guarding the fintech work process, and also availability of human resources for fintech. The core strategies or foundations that's needed in framework of Islamic fintech development are: Ability to manage and analyze data in big data era, and Human 
resources in digital marketing. For the aspects of Ecosystem or Actors involved and related in the development of Islamic fintech in Indonesia, the important actor is: Government or regulator, Educational institutions (universities), and also Existing industries (banks and other financial institutions).

\section{REFERENCES}

Ascarya, Widyo G, Widodo C, Enny A., dan Ferry S. (2012), Strategi Meningkatkan Preferensi Perbankan Syariah Indonesia Dalam Menggunakan Pembiayaan Bagi- Hasil. Jakarta: Central Banking Education and Studies Department, Bank Indonesia.

Bolanos et.al. (2005). "Using Interpretive Structural Modelling in Strategic Decision-Making Groups”. Management Decision 43 (6): 877-895.

Chuen, D.L.K., and Teo, E.G.S. (2015), "Emergence of fintech and the LASIC principles", The Journal of Financial Perspectives: Fintech, Winter 2015, pp. 24-37.

Devi, Abrista and Rusydiana, Aam Slamet (2016), "Islamic Group Lending Model (GLM) and Financial Inclusion", International Journal of Islamic Business Ethics Vol. 1 No 1, pp. 80-94.

Faisal, M.N., and Al-Esmael, B.A. (2014), "Modeling the enablers of organizational commitment", Business Process Management Journal, Vol. 20, No. 1, pp. 25-46.

Faisal, M.N. (2015), "A study of inhibitors to transparency in red meat supply chains in Gulf cooperation council (GCC) countries”, Business Process Management Journal, Vol. 21, No. 6, pp. 1299-1318.

Godet, M. (1986), "Introduction to 'la prospective': seven key ideas and one scenario method", Futures,
Vol. 18, No. 2, pp. 134-157.

Gorvett, R., and Liu, N. (2007), Using interpretive structural modeling to identify and quantify interactive risks. Orlando -USA: ASTIN Colloquium.

Harrison, R., Jaumandreu, J., Mairesse, J., and Peters, B. (2014), "Does innovation stimulate employement? A firm level analysis using comparable micro-data from four European countries", International Journal of Industrial Organization, Vol. 35, pp. 29-43.

Hasan, Shabana M. (2018), "Fintech in Indonesia: An Islamic outlook", article in EthisCrowd.com.

Jabeen, F., and Faisal, M.N. (2018), "Imperatives for improving entrepreneurial behavior among females in the UAE: An empirical study and structural model", Gender in Management: An International Journal, pp. 1754-2413.

Jabeen, F., and Faisal, M.N., and Katsioloudes, M.I. (2017), "Entrepreneurial mindset and the role of universities as strategic drivers of entrepreneurship evidence from the UAE", Journal of Small Business and Enterprise Development, Vol. 24, No. 1, pp. 136-157.

Kanungo S dan V.V. Batnagar, 2002. "Beyond Generic Models for Information System Quality : The Use of Interpretative Structural Modelling (ISM)". Journal of System Research and Behavior Science. Vol. 19 (2), P 531:549.

Lee, D. M. (2007). Structured Decision Making with Interpretive Structural Modelling (ISM). Canada: Sorach Inc.

Li, M., and Yang, J. (2014), “Analysis of interrelationships between critical waste factors in office building retrofit projects using interpretive 
structural modeling", International Journal of Construction Management, Vol. 14, No. 1, pp. 1527.

Marimin (2004), Pengambilan Keputusan Kreteria Majemuk. Teknik dan Aplikasi. Gramedia Widiasarana Indonesia. Jakarta.

Pollari, I. (2016), "The rise of fintech: Opportunities and challenges", The Finsia Journal of Applied Finance, Issue 3, 2016.

Ravi, V. (2015), "Analysis of interactions among barriers of eco-efficiency in electronics packaging industry", Journal of Cleaner Production, Vol. 101, pp. 16-25.

Rusydiana, Aam Slamet, and Devi, Abrista. (2018), "Mengembangkan koperasi syariah di Indonesia: Pendekatan interpretive structural model (ISM)“, Jurnal Economica, Vol. 9, No. 1, 2018.

Sage, A (1977), Interpretive Structural Modeling: Methodology for LargeScale Systems, McGraw-Hill, New York, NY, pp. 91-164.

Saksonova, S., and Merlino, I.K. (2017), "Fintech as financial innovation: The possibilities and problems of implementation", European Research Studies Journal, Vol. XX, Issue 3A, pp. 961-973.

Takkar, J., et.al. (2007). "Development of a Balanced Scorecard, An Integrated Approach of Interpretive Sructural Modeling (ISM) and Analytic Network Process (ANP)". International Journal of Productivity and Performance Management 56 (1): 25-59.

Venkatesh, V.G., Rathi, S., and Patwa, S. (2015), "Analysis on supply chain risks in indian apparel retail chains and proposal of risk prioritization model using interpretive structural modeling”, Journal of Retailing and Consumer Services, Vol. 26, pp.
153-167.

Warfield, J.N. (1974), “Developing interconnected matrices in structural modeling”, IEEE Transactions on System, Man and Cybernetics, Vol. SMC-4 No. 1, pp. 81-87.

Webster, I. And Pizalla, J. (2015), "Fintech: Are banks responding appropriately?" EY Publication 2015.

\section{ATTACHMENTS}

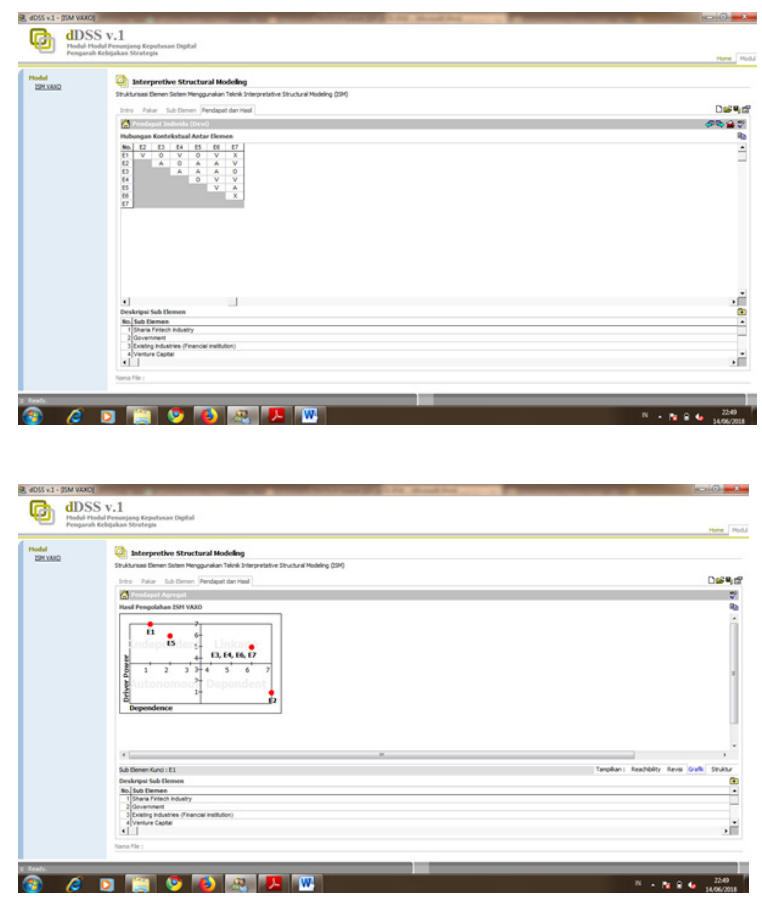

